УДК 339.5

DOI: https://doi.org/10.37320/2415-3583/11.5

Полякова Ю.В.

доктор економічних наук, доцент,

Львівський торговельно-економічний університет ORCID: https://orcid.org/0000-0002-8073-6186

\title{
ІННОВАЦІЙНИЙ КОМПОНЕНТ ЕКСПОРТНОЇ ДІЯЛЬНОСТІ
}

\begin{abstract}
Стаття присвячена оцінюванню інноваційної компоненти експортної діяльності Украӥни. Аналіз структури та динаміки вітчизняного експорту свідчить про наявність поряд із досягненнями низки недоліків. Застосування методу нечіткої логіки показує, що інноваційні витрати порівняно із іншими вхідними параметрами є нині наймени впливовим чинником для експорту. Одночасно з'ясовано, яку вагомість мають прямі іноземні інвестиції, інновачійні витрати, капітальні інвестииії та обсяги виконаних науково-технічних робіт для досягнення високих показників експортної діяльності. Отримані результати свідчать про необхідність обтрунтування заходів, пов'язаних із розвитком експортної діяльності на інновачійних засадах. Напрями стимулювання експорту охоплюють участь украӥнських суб' єктів у міжнародних інноваційних проектах, створення системи інституційного забезпечення експорту, запровадження комплексу економічних стимулів модернізачї виробництва.
\end{abstract}

Ключові слова: експорт, експортна діяльність, інновачійні витрати, експортоорієнтована стратегія, нечітка логіка

Постановка проблеми. Інновації та інвестиції виступають передумовою розвитку економіки, яка здатна генерувати експорт товарів із високою доданою вартістю, затребуваних на світовому ринку та стійких до зовнішніх коливань. Розвиток експорту є важливим пріоритетом для України в умовах відкритості економіки та інтегрування до світових господарських процесів.

Аналіз останніх досліджень i публікацій. Проведений нами аналіз наукових джерел із питань розвитку експортної діяльності показав значне розмаїття позицій науковців та їхніх поглядів щодо того, яким чином відбувається розвиток експорту. Багато дослідників орієнтуються лише на аналіз якихось певних аспектів, зокрема на заохочення діяльності експортоорієнтованих підприємств або територій, дослідження ключових викликів міжнародної торгівлі, оцінку експортних можливостей та експортного потенціалу. Проте загальне фокусування змістилося на 3'ясування пріоритетів та напрямів розвитку експортної діяльності на інноваційних засадах, що дає змогу отримувати стабільні і високі доходи від продажу товарів на світових ринках. Експортну діяльність досліджують С. Биткін, Г. Дугінець, О. Кордонська, В. Новіков, М. Серпухов та інші.

Мета статті полягає в оцінюванні вагомості прямих іноземних інвестицій, інноваційних витрат, капітальних інвестицій та обсягів виконаних науково-технічних робіт для розвитку експортної діяльності України.

Виклад основного матеріалу. Експорт країни $\epsilon$ відображенням ступеня розвитку і структури iï промислового виробництва та його загального технологічного рівня.

На взаємозв'язку між експортом та інноваціями наголошує В. Новіков, зазначаючи, що результатом інноваційної політики є обсяги продажу і частка в експорті високих технологій, решта - допоміжні показники, які можуть вплинути на здатність економіки пропонувати світу продукцію високих технологій [1]. На переконання Н. Микольської, експорт - це синергія складної взаємодії багатьох галузей. На практиці він не функціонує відокремлено, оскільки залежить від різних сфер, кожна з яких має певні алгоритми та завдання: транспортна інфраструктура, регулювання, освіта, трудові ресурси, інновації, інвестиції, кредитування, інформування [2].

Досвід іноземних країн, зокрема Німеччини, щодо зміцнення експортного потенціалу нерозривно пов'язаний із структурними перетвореннями економіки залежно від етапів формування моделі зовнішньоекономічних зв'язків (від поліпшення макроекономічних показників, формування виробничої, галузевої, підприємницької структури до підвищення технологічного рівня виробництва, освіти і кваліфікації персоналу) [3, с. 62].

Сучасні підходи формування інституційних засад підвищення спроможності України експортувати інноваційні товари та послуги згідно 3 крос-секторальною стратегією «Інновації для експорту» передбачають $[4$, с. 7$]$ :

- посилення інноваційної екосистеми, підтримку бізнес-середовища, яке сприятиме розвитку інновацій, підприємницької активності та експорту;

- розроблення фінансових послуг та інструментів підтримки бізнесу та інноваторів для розроблення і масштабування інноваційних товарів та послуг із високою доданою вартістю;

- розвиток навичок та компетенцій вітчизняних підприємців, менеджерів, науковців, інноваторів та компаній. 


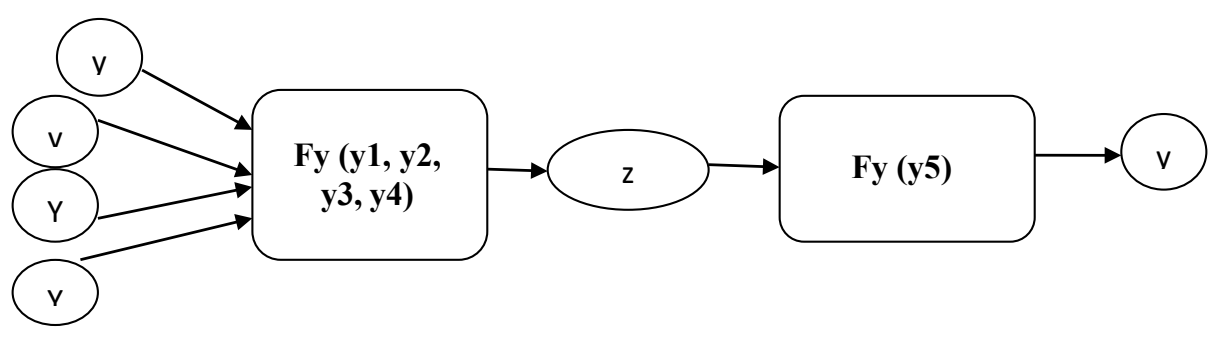

Рисунок 1 - Дерево логічних висновків

Для детальнішого розгляду особливостей досягнення ефективності експортної діяльності в Україні нами використано методи нечіткої логіки, враховуючи складність виявлення причинно-наслідкових зв'язків, невизначеність (за якістю і часом) результатів експортної діяльності. Вхідними змінними вибрані обсяги прямих іноземних інвестицій $\left(\mathrm{y}_{1}\right)$, обсяги інноваційних витрат $\left(\mathrm{y}_{2}\right)$, обсяги капітальних інвестицій $\left(\mathrm{y}_{3}\right)$, обсяги виконаних науково-технічних робіт $\left(\mathrm{y}_{4}\right)$, вихідними - обсяги експорту $\left(\mathrm{y}_{5}\right)$ згідно зі статистичними даними регіонів України у 2018 р. Виявлені причинно-наслідкові зв'язки між вхідними і вихідними змінними відображає «дерево» логічних висновків (рис. 1).

Під час створення правил моделі як вагові коефіцієнти взято коефіцієнти кореляції відповідних вхідних показників до вихідного (експорту). Нині інноваційні витрати $є$ найменш впливовим чинником для експорту порівняно із іншими вхідними параметрами.

Моделювання наведених параметрів дало змогу оптимізувати індикатори результативності експортної діяльності (табл. 2). За отрима- ними результатами 3'ясовано, що для досягнення середніх по Україні значень експорту недостатньо мати середній по Україні рівень прямих іноземних інвестицій, інноваційних витрат, капітальних інвестицій та обсягів виконаних науково-технічних робіт. Необхідно, щоб ці показники були вище середнього рівня. Оскільки для проведення дослідження показники були нормовані від нуля до десяти, то збільшення будь-якого показника від нуля до 6 дає менший виграш у експорті, ніж збільшення від 6 до 10. Чим меншими є вхідні показники, тим складніше піднімати експорт за рахунок зростання вхідних параметрів. Але якщо вони вже досягли вищого рівня, то тоді збільшувати експорт набагато легше.

Отримана модель показана у вигляді двох залежностей (рис. 2, рис. 3). Досягнення максимального рівня результативності інноваційної діяльності в регіонах можливе за таких передумов, як: обсяг прямих іноземних інвестицій не менше 17 372,5 млн дол. США; обсяг інноваційних витрат - 4213621,7 тис. грн; обсяг капітальних інвестицій - 182 093,2 млн грн.; обсяг виконаних науково-технічних робіт - 7718 179,6 тис. грн.

Таблиця 1 - Коефіціснти кореляції вхідних показників

\begin{tabular}{|c|c|c|c|}
\hline $\begin{array}{c}\text { Прямі іноземні } \\
\text { інвестиції }\end{array}$ & $\begin{array}{c}\text { Інноваційні } \\
\text { витрати }\end{array}$ & $\begin{array}{c}\text { Капітальні } \\
\text { інвестиції }\end{array}$ & $\begin{array}{c}\text { Обсяги виконаних } \\
\text { науково-технічних робіт тис грн }\end{array}$ \\
\hline 0,84 & 0,46 & 0,87 & 0,79 \\
\hline
\end{tabular}

Таблиця 2 - Перспективні оріснтири (умови) забезпечення оптимального рівня результативності експортної діяльності

\begin{tabular}{|l|l|l|l|l|}
\hline $\begin{array}{c}\text { Прямі іноземні } \\
\text { інвестиції, } \mathbf{y}_{\mathbf{1}} \\
\text { млн дол. США }\end{array}$ & $\begin{array}{c}\text { Обсяги інноваційних } \\
\text { витрат, млн грн, } \mathbf{y}_{\mathbf{2}} \\
\text { тис. грн. }\end{array}$ & $\begin{array}{c}\text { Капітальні } \\
\text { інвестиції, } \mathbf{y}_{\mathbf{3}} \\
\text { млн грн }\end{array}$ & $\begin{array}{c}\text { Обсяги виконаних } \\
\text { науково-технічних робіт, } \mathbf{y}_{\mathbf{4}} \\
\text { тис. грн. }\end{array}$ & $\begin{array}{c}\text { Експорт, } \mathbf{z} \\
\text { (нормований } \\
\text { показник) }\end{array}$ \\
\hline 5211,7 & 1264086,5 & 54627,9 & 2315453,8 & 3,65 \\
\hline 8686,2 & 2106810,8 & 91046,6 & 3859089,8 & 3,58 \\
\hline 12160,7 & 2949535,1 & 127465,2 & 5402725,7 & 4,52 \\
\hline 13898,0 & 3370897,3 & 145674,5 & 6174543,6 & 5,49 \\
\hline 15635,2 & 3792259,5 & 163883,8 & 6946361,6 & 7,65 \\
\hline 16503,8 & 4002940,6 & 172988,5 & 7332270,6 & 7,63 \\
\hline 17372,5 & 4213621,7 & 182093,2 & 7718179,6 & 5,72 \\
\hline 12160,7 & 4213621,7 & 182093,2 & 7718179,6 & 6,23 \\
\hline 17372,5 & 2949535,1 & 182093,2 & 7718179,6 & 5,68 \\
\hline 17372,5 & 4213621,7 & 127465,2 & 7718179,6 & 6,4 \\
\hline 17372,5 & 4213621,7 & 182093,2 & 5402725,7 & \\
\hline
\end{tabular}


Отримані аналітичні результати доводять важливість запровадження інвестиційно-інноваційних механізмів розвитку експортної діяльності. Така політика, на нашу думку, має здебільшого довгостроковий характер. Нині перелік товарів, що експортуються, відносно вузький, а суттєві зміни у технологічній структурі та географічній диверсифікації можливі у перспективі, що має певний часовий лаг.

Збереження сировинного характеру вітчизняного експорту і висока залежність економіки від глобальних ринків знижує можливості отримання додаткової доданої вартості та свідчить про необхідність стимулювання експортної активності перспективних галузей із глибоким ступенем переробки, що передбачає їхню модернізацію, яка залежить від проміжного споживання імпортного обладнання та трансферу технологій $[5$, с. 16].

O. Кордонська наголошує на побудові експортоорієнтованої стратегії за принципом smart [6, c. 28]: s (streamlined - цілеспрямований) - дає змогу досягти бажаного результату найбільш ефективним способом; m (meaningful - значущий) - позитивно впливає на економіку держави; a (adaptable - адаптивний) - здатний адаптуватися до змін середовища; r (relevant актуальний) - успіх визначається сучасним станом та менталітетом нації; $\mathrm{t}$ (transparent - прозорий) - побудований на основі якісного і прозорого інституційного середовища.

Серед перешкод, що стримують розвиток експорту на основі інновацій, у крос-секторальній експортній стратегії «Інновації для експорту» називають: розбіжності між інноваціями, що створюються бізнесом, та наявним попитом на ринку; недостатній доступ до інформації про наявні ресурси і бізнес-можливості для інновацій та досліджень; відсутність стратегічного погляду та чітко визначених пріоритетів в інноваційній сфері; недосконалу національну інноваційну сис-

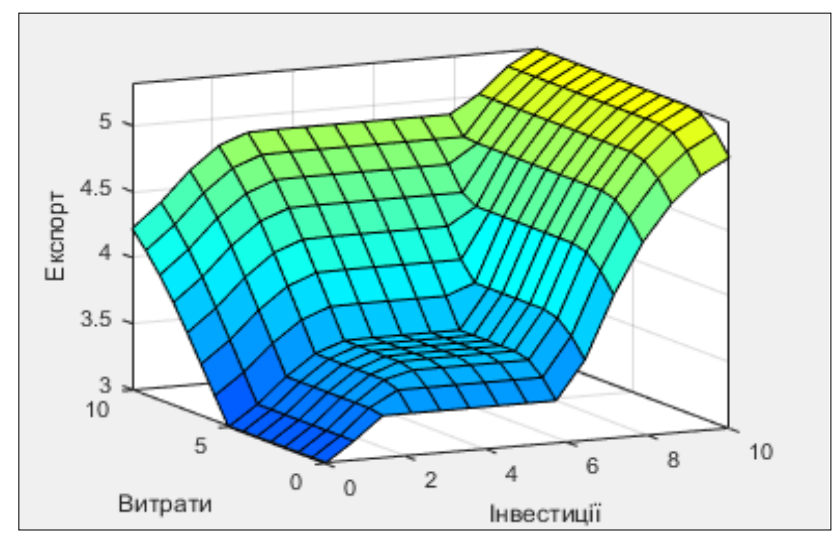

Рисунок 2 - Залежність експорту від інноваційних витрат та прямих іноземних інвестицій тему; незначну кількість організацій, спроможних швидко створювати інноваційні продукти, готові до експорту через фінансові інструменти та технічну інфраструктуру [4, с. 26].

Розвиток експортної діяльності на основі інновацій має відбуватися на основі діючої кроссекторальної стратегії «Інновації для експорту» та передбачати урахування існуючих бар'єрів внутрішнього та зовнішнього походження, обгрунтування секторів і галузей, пошук перспективних ринків, окреслення можливостей стимулювання експорту за допомогою низки заходів та інструментів.

Пошук перспективних ринків має відбуватися на основі урахування ринкових факторів (обсяги ринку, динаміка зростання, еластичність попиту, стан конкурентного середовища); інформаційних бар'єрів (інформація про ринки збуту, параметри самого ринку за окремою товарною групою та географічною ознакою); інфраструктурних обмежень (логістичні, фінансові, ринкові, валютні обмеження); експортного потенціалу підприємства (потенційні можливості підприємства 3 виробництва та експорту продукції на зовнішні ринки або імпортозаміщення на внутрішньому ринку); зовнішньоторговельних бар'єрів (правила та норми, які обмежують можливості збільшення обсягу зовнішньоекономічної діяльності) [7, с. 8].

Серед пріоритетних напрямів стимулювання експорту слід виділити: 1) участь українських суб'єктів у європейських інноваційних проектах, зокрема технологічних платформах; 2) створення системи інституційного забезпечення як платформи взаємодії для консультаційного, інформаційного, маркетингового та технічного супроводу експорту; 3) запровадження економічних стимулів для модернізації виробництва, що має експортні перспективи.

Стосовно участі вітчизняних підприємств у Європейських технологічних платформах наго-

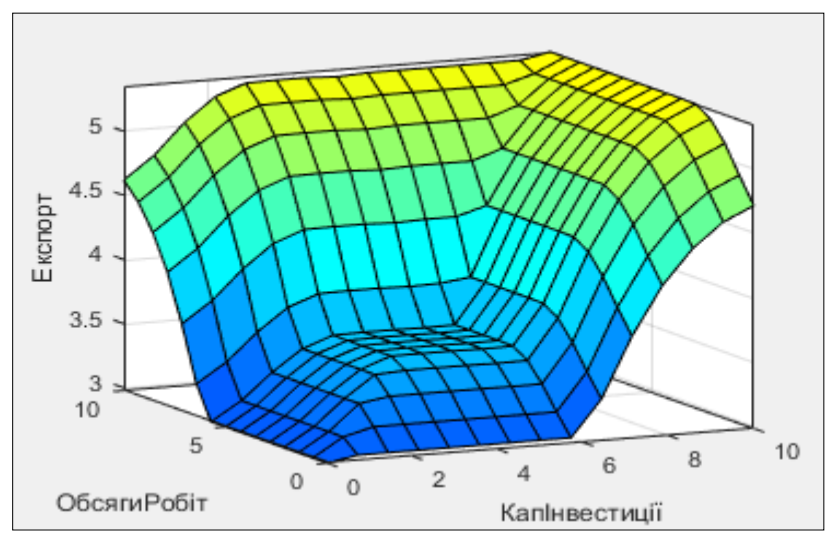

Рисунок 3 - Залежність експорту від обсягів науково-технічних робіт та капітальних інвестицій 
лосимо, що останні функціонують як форма ділового партнерства та інструмент комунікації у напрямах, що відображають науково-технічний прогрес і сприяють забезпеченню конкурентоспроможності стратегічних галузей. Дослідницькі пріоритети та потреби розвитку промисловості $\epsilon$ їхніми ключовими інтеграційними детермінантами. Важливою характеристикою технологічних платформ є об'єднання зусиль академічної спільноти i дослідницьких інститутів, фінансових i державних структур, промисловості, великого бізнесу та галузевих об'єднань і включення до складу учасників представників міжнародних об'єднань або інших країн. Мобілізація зусиль зацікавлених сторін на інноваційному розвитку за певним галузевим напрямом, формування науково-виробничих коопераційних зв'язків дасть змогу вітчизняним суб' єктам увійти до нових ланцюгів створення доданої вартості та експортної діяльності.

Наголошуємо на важливості обізнаності підприємств в усіх аспектах, пов'язаних із здійсненням експортних операцій, що дає змогу досягати поставлених цілей. Тому саме функціонування своєрідного майданчику (платформи) взаємодії між експортерами та державними або громадськими установами набуває актуальності. Проте, для прикладу, про існування Офісу із просування експорту, установи, яка надає послуги та консультації експортерам, знає лише одна четверта частина опитаних Інститутом економічних досліджень та політичних консультацій експортерів. Експортери також зазначають про недостатню кількість джерел для отримання інформації про ситуацію в країнах-партнерах; неповну відповідність переліку послуг, які надають бізнес-асоціації, їхнім потребам; відсутність помітних змін у діяльності окремих інституцій сприяння експорту; надання переваги вітчизняним джерелам отримання інформації, аніж іноземним; обмеженість у використанні інформації стосовно експорту на сайтах офіційних інституцій [8, с. 143-152].

Стимули для модернізації наявної виробничої структури передбачають податкові та митні пільги для ввезення сучасного обладнання, що використовується для виробництва експортної продукції; зменшення вартості експортних кредитів, страхування та спрощення вимог до документарного оформлення експортних операцій. Активізації експортної діяльності також сприятиме укладання угод про вільну торгівлю 3 країнами, що $є$ перспективними ринками, та реалізація заходів, пов'язаних із усуненням або зменшенням негативного впливу бар'єрів, які існують у торговельній сфері.

Висновки. Експортна діяльність тісно пов'язана із структурними перетвореннями економіки, інновації набувають вагомої ролі для реалізації експортного потенціалу. Проте нині інноваційні витрати $\epsilon$ найменш впливовим чинником для вітчизняного експорту. Пріоритетами стимулювання експорту є інтеграція до європейських інноваційних проектів, створення дієвої системи супроводу експорту та застосування економічних стимулів модернізації виробничої структури.

\section{Список використаних джерел:}

1. Новіков В. Чому інноваційна стратегія України не пов'язана з економічним зростанням. Економічна правда. 2019. 17 жовтня. URL: https://www.epravda.com.ua/columns/2019/10/17/652482 (дата звернення: 16.02.2020).

2. Микольська H. Яким бути українському експорту. Завдання на наступні п’ять років. URL: https://www.eurointegration.com.ua/experts/2017/04/11/7064346 (дата звернення: 11.02.2020).

3. Третяк В.В., Рязанова Н.О. Визначення перспектив реалізації експортного потенціалу регіону (на прикладі Луганської області): монографія. Луганськ: вид-во «Ноулідж», 2013. 184 с.

4. Крос-секторальна експортна стратегія «Інновації для експорту». URL: http://www.me.gov.ua (дата звернення: 18.01.2020).

5. Розвиток промисловості для забезпечення зростання та оновлення української економіки : науково-аналітична доповідь / за ред. Л. В. Дейнеко. Київ: ДУ «Ін-т екон. та прогнозув. НАН України», 2018. 158c.

6. Кордонська О. Експортоорієнтовані стратегії у глобальній економіці: монографія. Львів: Бадікова Н. О., 2017.300 с.

7. Активізація експортної діяльності підприємств України: недоторговані ринки та торгівельні бар'єри / за ред. М. Ю. Серпухова. Харків: вид-во Лідер, 2019. 216 с.

8. Спрощення процедур торгівлі в Україні: оцінки та очікування бізнесу: аналітичний звіт за результатами четвертої хвилів щорічного опитування українських імпортерів та експортерів / Інститут економічних досліджень та політичних консультацій. Дніпро: Середняк Т. К., 2019. 165 с.

\section{References:}

1. Novikov V. (2019) Chomu innovatsiina stratehiia Ukrainy ne poviazana $\mathrm{z}$ ekonomichnym zrostanniam [Why Ukraine's innovation strategy is unrelated to economic growth]. Ekonomichna pravda, 17 of October. Available at: https://www.epravda.com.ua/columns/2019/10/17/652482 (accessed 16 February 2020).

2. Mykolska N. Yakym buty ukrainskomu eksportu. Zavdannia na nastupni piat rokiv [How to be Ukrainian export. Tasks for the next five years]. Available at: https://www.eurointegration.com.ua/experts/2017/04/11/7064346 (accessed 11 February 2020).

3. Tretiak V.V., Riazanova N.O. (2013) Vyznachennia perspektyv realizatsii eksportnoho potentsialu rehionu (na prykladi Luhanskoi oblasti) [Determination of prospects for realization of export potential of the region (on the example of Lugansk region)]. Luhansk: Noulidzh. (in Ukrainian) 
4. Ministry of Economic Development, trade and agriculture of Ukraine (2019) Kros-sektoralna eksportna stratehiia "Innovatsii dlia eksportu” " [Cross-Sectoral Export Strategy for Innovation for Export]. Available at: http://www.me.gov.ua (accessed 18 January 2020).

5. Deineko L.V. (ed) (2018) Rozvytok promyslovosti dlia zabezpechennia zrostannia ta onovlennia ukrainskoi ekonomiky : naukovo-analitychna dopovid [Industry Development for Growth and Renewal of the Ukrainian Economy: Scientific and Analytical Report]. Kyiv: Institute for Economics and Forecasting National Academy of Science of Ukraine. (in Ukrainian).

6. Kordonska O. (2017) Eksportooriientovani stratehii u hlobalnii ekonomitsi [Export-oriented strategies in the global economy]. Lviv: Badikova. (in Ukrainian).

7. Serpukhov M. (ed) (2019) Aktyvizatsiia eksportnoi diialnosti pidpryiemstv Ukrainy: nedotorhovani rynky ta torhivelni bariery [Activation of export activity of Ukrainian enterprises: underdeveloped markets and trade barriers]. Kharkiv: Lidrer. (in Ukrainian).

8. The Institute for Economic Research and Policy Consulting (2019) Sproshchennia protsedur torhivli v Ukraini: otsinky ta ochikuvannia biznesu: analitychnyi zvit za rezultatamy chetvertoi khvyliv shchorichnoho opytuvannia ukrainskykh importeriv ta eksporteriv [Trade Facilitation in Ukraine: Business Estimates and Expectations: Analytical Report on the Results of the Fourth Wave of Ukrainian Importers and Exporters Annual Survey]. Dnipro: Seredniak T. K. (in Ukrainian).

Poliakova Juliia

Lviv University of Trade and Economics

\section{INNOVATION COMPONENT OF EXPORT ACTIVITIES}

The article is devoted to assessing the role of foreign direct investment, innovation expenditures, capital investments, and the volume of scientific and technical work performed for the development of export activities. It is found that export is a synergy of interaction among many industries, the functioning of which determines the success of the implementation of export strategies. The experience of European countries shows that strengthening export potential is inextricably linked to structural changes in the economy. The need to develop export activity, sales of goods with high added value on the world market and successful integration in international trade determine the relevance of the topic for the domestic economy which is mostly concentrated in traditional sectors with low activity in the field of research and development and dependent on external conditions. The application of the fuzzy logic method shows that innovation costs compared with other input parameters are the least influential factor for domestic exports today. At the same time, it was found out what importance foreign direct investment, innovative spending, capital investment and the volume of scientific and technical work have to achieve high export performance. Modern approaches to forming the institutional framework for improving Ukraine's ability to export innovative goods and services in accordance with the cross-sector strategy include strengthening the innovation ecosystem, business environment support, financial services and tools development to support businesses and innovators as well as development of skills and competencies of domestic companies. The directions of stimulating domestic exports cover a set of measures and instruments of an institutional, organizational and economic nature. Among them, it is advisable to highlight the integration of innovative projects in Europe, the formation of an effective system of institutional support for exports, increasing the level of information awareness of exporters, the introduction of economic mechanisms for innovative development or technological production with export prospects.

Key words: export, export activity. innovative costs, export-oriented strategy, fuzzy logic.

JEL classification: F10, F13, F14. 